\title{
THE ENVIRONMENTAL PERFORMANCE AND COST OF INNOVATIVE TECHNOLOGIES FOR DUCTILE IRON FOUNDRY PRODUCTION
}

\author{
Rose M. Torielli, Fred S. Cannon and Robert C. Voigt \\ The Pennsylvania State University, University Park, PA, USA \\ Timothy J. Considine \\ University of Wyoming, Laramie, WY, USA \\ James C. Furness \\ Furness Newburge, Inc., Versailles, KY, USA \\ John T. Fox \\ Lehigh University, Bethlehem, PA, USA \\ Jeff E. Goudzwaard \\ Neenah Industries, Inc., Neenah, WI, USA \\ He Huang \\ URS Corporation, Philadelphia, PA, USA
}

Copyright @ 2014 American Foundry Society

Abstract

\begin{abstract}
The authors and collaborators have devised innovative technologies that decrease foundry costs, pollution, materials use, and energy. These include: (a) applying advanced oxidation to green sand and baghouse dust to diminish clay, coal, sand, volatile organic compounds (VOCs), and costs; (b) replacing phenolic urethane core binders with collagen-alkali silicate binders to diminish VOCs; (c) replacing coke with anthracite fines held together with biomaterial to reduce energy and costs. It is proposed by the authors that if a foundry were to concurrently employ all these innovative technologies (with $50 \%$ anthracite bricks), it could potentially diminish overall costs
\end{abstract}

by $6.6 \%$, life cycle energy costs by $15 \%$, VOC pollution by $57 \%$, sand by $85 \%$, clay and coal by $50 \%$, and iron scrap by $9 \%$. These computations are per full-scale operations for advanced oxidation; and $R \& D$ results for replacing binders and coke. This paper also notes that when electricity comes primarily from coal fired power plants, electric induction furnaces consumes more life cycle energy than do cupolas for melting iron.

Keywords: metalcasting, foundry, cupola, advanced oxidation, coke, energy, materials, volatile organic compound emissions, anthracite, ultrasonics, life cycle, sustainability

\section{Introduction of Innovative Foundry Technologies}

Over the course of 15-20 years, a team has been devising innovative sustainable technologies for the metalcasting industry, with particular focus on cast iron foundries. The collaborative team includes university researchers, development entrepreneurs, and foundry personnel who have developed the following technologies: 1. Application of advanced oxidants and hydroacoustic cavitation to spent green sand and baghouse dust in a manner that restores the binding activity of the clay and sand. This process saves costs by diminishing clay, coal, and sand use, while also diminishing air pollution from volatile organic compounds (VOCs) and hazardous air pollutants (HAPs). 2. Replacement of conventional phenolic urethane core binders with low-polluting core binders comprised of hydrolyzed collagen, alkali silicates and other additives. This can cut VOC pollution to one-third the amount.
3. Replacement of conventional metallurgical coke in cupolas with anthracite fines formed into bricks with hydrolyzed collagen, lignin, and other additives. The bricks burn as fast as coke, while hosting 35\%-40\% higher energy per volume than coke. Coke is made by carbonizing bituminous coal at high temperatures $\left[1100^{\circ} \mathrm{C}\left(2012^{\circ} \mathrm{F}\right)\right]$ for $28-30$ hours in an oxygen-deficient atmosphere in order to concentrate the carbon. This coking process consumes 15\%-20\% of the energy initially present in the coal. In contrast, the brick-making requires considerably less energy, since high-temperature preheating is not required. These bricks include components otherwise wasted or offering little economic value.

Advanced oxidation processes have been commercially available for about 20 years and installed on 60 foundry lines. The initial advanced oxidation system included hydrogen peroxide, ozonation, and sonication and employed 
a blackwater clarifier. This system now has been placed on 50 full-scale foundry lines that can make $10 \%$ of America's cast iron. Herein, this is referred to as an advanced oxidation-blackwater clarifier system (AO-BW), a proprietary system made by an American company. The team has conducted considerable research on this process. ${ }^{1-11}$ The costs, materials uses, and life cycle savings of this process are based on actual data from full-scale operations at foundries. The authors have presented cost savings for these innovative technologies in terms of percent change relative to a baseline conventional cupola foundry. This normalized relative comparison is used rather than quantitative dollar values to respect the confidentiality of the collaborating foundries.

The advanced oxidation system recently has been enhanced to include hydroacoustics- cavitation and virtual cyclone..$^{12-14}$ This enhanced system has been installed on ten foundry lines and is referred to as the advanced oxidation-hydroacoustic cavitation-virtual cyclone system (AO-HAC) herein, a proprietary system made by an American company. The costs, materials uses, and life cycle saving of this process are also based on actual full-scale operations at Neenah Foundry, and other foundries.

With regard to replacing the metallurgical coke as the fuel source in a cupola, with anthracite fines formed into a brick and held together with a collagen-silicate binder, the collaborative team has conducted considerable research and development. ${ }^{15-22}$ The technology has been successfully demonstrated in recent full-scale trials at foundries. The costs and life cycle appraisals are based both on the bench-scale performance and on the pilot-scale and full-scale demonstrations, as projected to continuous operations.

The authors also have devised a means of using a cupola's exhaust heat to activate lignite coal in-situ and employing the activated lignite as a VOC adsorbent or coke replacement. The lignite and sorbed VOCs can be used as a green sand additive. Key features of the lignite activation also have been researched and demonstrated. ${ }^{23,24}$

In this paper, the authors also have appraised the environmental life cycle and costs of melting iron in conventional cupolas compared to electric induction furnaces. When coalfired power plants are used to generate electricity (as for the subject foundries in the Midwest), electric induction furnaces are more costly, require more electric life cycle coal energy, and involve greater air emissions than do cupolas. These appraisals of melting costs are based on full-scale performance at collaborating foundries ${ }^{25}$ and publicly available data.

\section{Introduction to Cost, Energy, and Environmental Life Cycle Analyses}

The metalcasting industry is an iron and steel recycling engine in which iron scrap use is roughly equal to industry shipments. The authors and collaborators have developed several innovations for materials use that are available for the industry to become even more sustainable. The objective of this article is to describe these innovations and estimate their environmental, energy, and economic impacts.

Gray and ductile iron castings together constitute more than $70 \%$ of all cast metals. The U.S. is the world's third largest producer of gray iron castings and is the largest producer of ductile iron castings, providing $25 \%$ of the world's ductile iron. The metalcasting industry is a major manufacturing sector in America that employed 121,100 people in 2011, 41,100 of whom worked in iron foundries. In 2011, roughly 11 million tons of metal castings were produced in 2,010 foundries. Ninety percent of all manufactured products and capital goods contain metal castings.

Cost-effective cast iron production relies upon the availability of iron and steel scrap and automated green sand molding systems. The U.S. metalcasting industry faces worldwide competition for low cost, high-grade iron and steel scrap and ever tightening air quality standards. Technological innovation involving materials is essential, because for many foundries, raw materials costs are the single largest cost of production.

Conventional end-of-pipe emission controls can add substantially to capital investment and operating costs for a foundry. In contrast, the authors believe the innovations in this paper can reduce costs by treating the source of the emissions as a resource to be utilized. These technologies also reduce emissions of VOCs, enabling compliance with increasingly stringent standards set by the U.S. Environmental Protection Agency, while improving goodwill in communities located near casting facilities.

This study evaluates the energy and materials flows for cast iron foundries to better understand the costs and environmental benefits of the sustainable technologies currently under deployment in the industry, as well as those nearing commercialization. Specifically, advanced oxidation systems have been installed in numerous facilities systems for recycling baghouse dust and sand from green sand mold making. Promising binder technologies that reduce VOCs during metalcasting and replace coke in hot metal production are undergoing full-scale testing. The new binder systems replace materials posing high VOC emission profiles with substitute materials that are waste products from nonfoundry processes with otherwise low economic value.

\section{Ductile Iron Foundry Production}

A conventional iron casting facility involves: (1) coremaking and molding; (2) molten metal preparation; and (3) pouring, cooling, shakeout, and finishing. In the first step, molds are made of green sand. Green sand is composed of silica sand $(82-89 \%)$, bentonite clay $(5-7 \%)$, seacoal (or fusible bituminous coal) $(3-5 \%)$, water $(2-4 \%)$, core binders $(0-1 \%)$, and cereal $(<1 \%)$. Seacoal (high quality coal with $30-35 \%$ low 
ash bituminous coal) provides a reducing atmosphere during pouring that reacts with incidental oxygen to prevent oxidation and provide a lustrous finish to the product. Sand cores conventionally are held together with phenolic urethane, which is cured with amine gases. Other conventional organic binders are also sometimes used but are beyond the scope of this paper. The green sand mold and cores are formed to create a cavity into which molten iron is poured. The molten iron casting solidifies into the shape of this cavity.

After the casting solidifies, the sand materials are shaken to dislodge them from the iron product. These materials are reconditioned by blending with a small amount of new sand, clay, and coal and then re-circulated. In conventional operations, the phenolic urethane binder in the sand cores is partly pyrolyzed, which causes the release of VOCs, some of which are HAPs. In conventional operations, after 10-20 passes through the molding system, the carbon-coated sands and clays become hydrophobic and are conventionally disposed as solid waste, along with fired clay and sand fines. ${ }^{9}, 10$ For each ton of iron castings produced, the foundry must recirculate 5-10 tons of green sand. Overall, waste green sand from all types of metal castings amounts to 3-5 million tons annually in the U.S.

During molten metal production, the iron and alloys are melted in either a cupola or conventional induction electric furnace. During melting, impurities combine with calcium carbonates and silicates and float to the surface as slag. In cupolas, the main conventional source of energy for melting the iron is coke. The coke also adds carbon to the final alloy mixture. The process of making foundry coke is energy and emissions intensive.

Finishing the iron product requires removing the green sand and cores from the casting surface by vibratory shakeout. Workers then shot blast and grind the castings and produce a finished product. Iron parts that do not meet quality standards are recycled as in-plant iron scrap. For every ton of iron poured, conventional green sand foundries typically yield 0.60.8 tons of marketable metal products. The remaining mass represents risers, sprues (metal in access ports), scrap (rejects), and returns for re-melting. For every ton of metal poured, a conventional mechanized foundry consumes 20-30 million British Thermal Units (BTU) of energy, 250-600 pounds of silica sand, 100-200 pounds of coal and clay, 0-20 pounds of phenolic urethane binder, and 0-4 pounds of cereal. . $^{5}$

\section{The Life Cycle Environmental and Cost Model}

To compare the resource use, emissions profile, and cost of existing and prospective iron casting technologies, a model measuring these features has been required. This baseline model is calibrated for an actual cupola-based iron foundry located in Wisconsin. The baseline case includes cupola melting using foundry metallurgical coke, conventional green sand molding, no recycling of baghouse dust or sand, and no innovations for releasing the sands or clays from their carbon-coating. The baseline case also considers the use of phenolic urethane cores cured with amine gas. The basecase model is subsequently used to estimate the impacts of adopting the sustainable production technologies.

The life cycle boundaries include major upstream activities that supply inputs to iron casting facilities. Within the foundry, the model accounts for energy, materials use, environmental emissions, operating costs, and capital costs. These metrics are tracked at each intermediate stage of production. These stages include hot metal making, coremaking, green sand molding, pouring, cooling, and shakeout. Downstream recycling of iron products and their recovery are not considered because the innovative process technologies under study would not be affected by their adoption. The data inputs to this life cycle and cost model have included management reports from actual foundries, the publications of the research team, ${ }^{1-24}$ as well as numerous publicly available sources. ${ }^{27-35}$

Figure 1 illustrates the baseline input-output boundaries for the analysis. The major upstream activities - power production, coke making, and sand mining-provide inputs of electricity, coke, and sand respectively, requiring fuels and raw materials and generating emissions. Cupola melting and the balance of foundry activities are the two major functional units depicted on the left of Figure 1. These activities require melting inputs, such as ferrous metal alloys, scrap metal, and natural gas. They also require process inputs, such as parts and supplies. This entire process chain, from primary fuels and material production through the plant gate, produces finished cast iron products and (potential) environmental discharges.

Cost and usage data are based on 2005 management reports by the foundries, as adjusted in real terms to 2010 dollars. Other costs equal the product of input requirements per unit of intermediate or final output by the unit market value of the commodity or fuel. These costs and usages are normalized to relative percent change offered by the sustainable technologies, to respect the confidentiality of the collaborating foundries. Simple payback is calculated by dividing estimated investment cost by the calculated annual savings.

For unit processes other than pouring, cooling, and shakeout, the baseline emissions data are from reported stack tests performed at Neenah Foundry in 2005, supplemented by the EPA's AP-42 Compilation of Air Pollutant Emission Factors: Stationary Point and Area Sources and other EPA Emission documents by the U.S. EPA. ${ }^{36,37}$ This life cycle study also estimates $\mathrm{CO}_{2}$ released from burning coal or coke and from calcining limestone based on the material usage and solid waste disposal reported by the partner foundries. For example, the cupola melting process emits greenhouse gasses due to combustion of incoming fuels and reactions of input materials such as limestone and limespar. This analysis assumes the complete combustion of the carbon not accounted for in the reported input / output streams into 
$\mathrm{CO}_{2}$. When innovative technologies are compared, emission changes are based on those reported in literature ${ }^{1-24}$ or on the reduction in material or energy usage reported and calculated as stated above.

\section{Cupola Melting}

The inputs for the cupola melting include steel and cast iron scrap, pig iron, ferroalloys, silicon, alloys, and carbon. Coke generates the major energy input and provides alloy carbon. Limestone is used to flux and clean the metal of unwanted elements. Oxygen is injected into the cupola, to increase the melt rate and raise the cupola temperature. On the exterior of the cupola, a water jacket cools the furnace shell. Electricity powers the air blowers, water pumps and other equipment. Natural gas feeds the afterburners to complete the combustion of carbon monoxide $(\mathrm{CO})$ to carbon dioxide $\left(\mathrm{CO}_{2}\right)$, and combust other carbonaceous volatiles that exit the cupola. The output of the process is molten iron and slag. For this analysis, a wet scrubber captures the particulate emissions with sludge as a solid waste output. The $\mathrm{CO}_{2}$ emissions reflect complete combustion of all carbon not in the iron product or the slag. ${ }^{25}$

\section{Melt Handling}

As the molten metal exits the cupola furnace, it flows to an electric holding furnace, where metallic alloys are added.
The pouring ladles are pre-heated with natural gas. The output for this process is the molten metal, which proceeds to the pouring system. Greenhouse gas emissions are computed based on the $\mathrm{CO}_{2}$ resulting from combusting natural gas.

\section{Coremaking, Green Sand Molds, Pouring, Cooling, Shakeout, and Baghouse Dust Collection}

Conventional coremaking employs the phenolic urethane cold box process. The material inputs for this process include new silica sand, phenolic urethane binder, and triethylamine (TEA) or diethylmethylamine (DEMA) gas for curing. Compressed air, natural gas, and electricity are also consumed during this process. When the core is exposed to heat from molten metal, the heat releases VOC emissions. ${ }^{19}$

Molds are conventionally made from recirculated green sand, new sand, bentonite clay, seacoal, soda ash, cereal and water. After pouring, cooling, shakeout, and reprocessing, a portion of the returned green sand is discarded as solid waste. Compressed air, electricity, and natural gas are used in this process. Dust is created when the sand is mixed and reconditioned; an air exhaust system sends this dust to a baghouse. In conventional systems, the baghouse dust is wasted to a landfill.

The mold then is moved to the pouring position. During molten iron exposure, the organic materials in the green

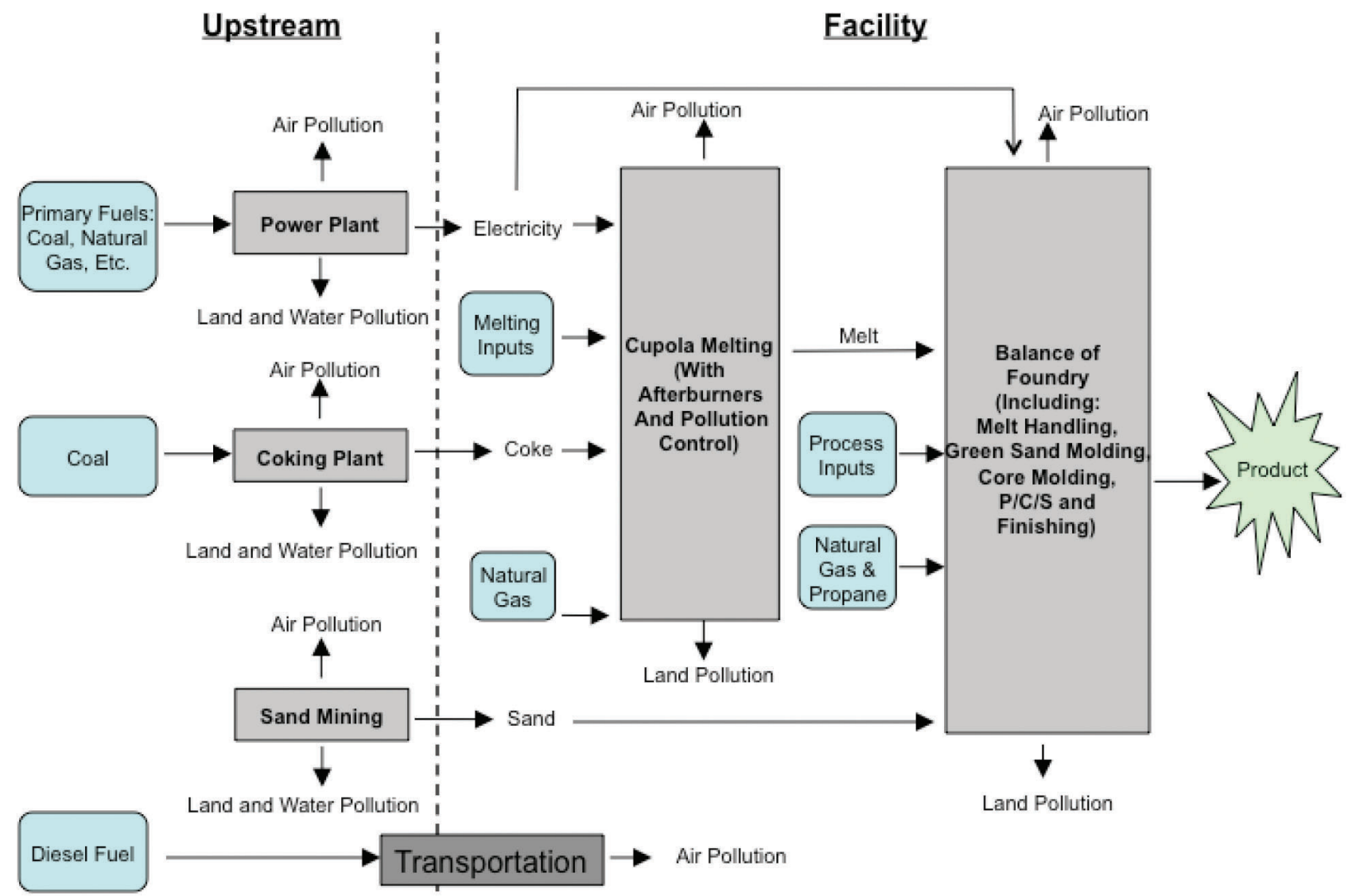

Figure 1. Conventional cupola foundry: Baseline input-output boundaries. 
sand mold and cores experience pyrolysis and some combustion. Particulate air emissions are based on partner foundry data. The VOC and greenhouse emissions data for pouring, cooling, and shakeout have been taken from Neenah Foundry, ${ }^{4}$ a full-scale demonstration foundry in Sacramento, Calif., ${ }^{3}$ and several other full-scale foundries. ${ }^{1}$ The remaining outputs to the process are the unfinished cast parts and in-house scrap.

\section{Metal Finishing and Compressed Air}

During metal finishing, the cast parts are shot-blasted; which is a very labor-intensive process, requiring electricity for equipment and propane for lift trucks. The material outputs are cast parts and scrap for the cupola. The finishing area has a baghouse for particulate emissions that become solid waste. Air emissions are generated by the combustion of the lift truck propane and traced as $\mathrm{CO}_{2}$.

The subject foundry also has centralized facilities to produce compressed air, which require electricity. The energy needed for compressed air then is apportioned throughout the plant to the processes that use it.

\section{Upstream and Off-Site Life Cycle Considerations}

This study also estimates energy and material use in the upstream activities and related emissions that provide inputs to the foundry. The acquisition costs of these materials include production and transportation. Sand mining includes extraction as documented by Alsema et al. ${ }^{27}$ Transportation energy and emissions are based on ton-miles required, employing diesel-fueled trucks, per U.S. Energy Information Administration (EIA) $)^{32}$ and data reported by Davis et al., ${ }^{29}$ Rodrigue et al. ${ }^{31}$ and Baumel et al. ${ }^{28}$ The baseline foundry and the sand source are both located in Wisconsin.

The conventional coking process includes (a) transportation of bituminous coal from West Virginia and Pennsylvania to the coke plant in New York or northwestern Pennsylvania; (b) coking coal production; and (c) transportation of coke to the foundry in Wisconsin. Transportation costs of coal and coke are computed based upon rail and truck data reported by Rodrigue et al. ${ }^{31}$ and U.S. EIA. ${ }^{33}$ The diesel fuel consumption and $\mathrm{CO}_{2}$ emissions are calculated by the same methods used for sand mining. For the coking process, the estimates for energy and emissions are from the report by Considine, et al., ${ }^{26}$ as adjusted to account for the prolonged pyrolysis required for foundry metallurgical coke compared to coke used in steel-making.

With regard to clay and coal, the conventional baseline appraisal includes truck transportation of these materials. Clay is composed of a mixture of western bentonite from Wyoming [ $\mathrm{Na}$ as cation] and southern bentonite from Georgia [Ca as cation]. Seacoal originates from West Virginia, western Virginia, and southwestern Pennsylvania.
Fuel use and emissions in the generation of electricity is based upon data for Wisconsin reported by U.S. EIA. ${ }^{34}$ The energy units used by other processes to produce electricity were apportioned to the fuel types in the profile. This framework has been employed herein to estimate the impacts of foundry process choices.

\section{Electric Induction Furnaces Versus Cupolas for Melting Iron}

Cupolas and conventional electric induction furnaces each produce about half of the U.S. cast iron. Since cupolas are charged with limestone, they can accommodate scrap iron and carbon sources that include higher proportions of impurities. Batch electric induction furnaces use electricity for melting and require more expensive (i.e. purer) iron and carbon sources for alloying the metal. Overall, the electric induction furnace requires $207 \%$ more fossil energy and $207 \%$ more non-fossil energy to melt iron than does a foundry cupola (see Table 1). This profoundly higher energy demand is because of the higher relative inefficiencies in transmitting electrical power, and converting heat energy to electrical energy and then back to heat energy. However, the actual cost of energy for the electric induction furnace is only $9.7 \%$ higher than for the cupola because the metallurgical coke used in cupolas costs considerably more than the coal used in power plants. The authors note that utilizing anthracite fines formed into bricks in cupolas can help mitigate the large cost differential (as discussed below).

Table 1. Impacts of Replacing the (baseline) Cupola with Electric Induction Furnaces for Melting Iron: Impacts in Percentage Changes from Base

\begin{tabular}{lr}
\hline \multicolumn{2}{c}{$\begin{array}{c}\text { Total System Including Foundry plus } \\
\text { (+ increase, - reduction) }\end{array}$} \\
\hline Energy & 206.7 \\
Fossil & 206.9 \\
Non-fossil & \\
Emissions & 58 \\
$\quad$ Greenhouse gas & 150 \\
Criteria pollutants & -28.3 \\
Particulates & 88 \\
VOCs & \\
& \\
\hline Materials & -100.0 \\
Coke (as alloy) & 81.8 \\
Scrap \& other materials & \\
Costs & 9.7 \\
Energy & -0.8 \\
Labor & 2.4 \\
Materials & -0.9 \\
Other Cost & 1.7 \\
Total \\
\hline Electric induction furnaces melt about half of all iron \\
in the US. \\
Non-fossil fuel includes nuclear, hydro, solar, wind \\
and other sources used for electrical generation. \\
\hline
\end{tabular}


Operating cupolas generate local environmental impacts via air emissions. Electric induction furnaces generate fewer emissions onsite than cupolas. One attractive option therefore, is to replace cupolas with electric induction furnaces, to avoid these local impacts and associated regulatory permits. Several foundries have adopted this option in response to local air quality rules that limit the emissions from the cupola but it is not favorable from an overall life cycle perspective.

Specifically, replacing the cupola with an electric induction furnace merely transfers emissions upstream to the electricity-producing sector, as illustrated by the impacts reported in Table 1. While emissions of particulates are lower for the electric induction furnace option than the baseline cupola option, life cycle emissions of criteria air pollutants increase $150 \%$ when electric induction furnaces are used. Greenhouse gas emissions also are 58\% higher, and emissions of VOCs are $88 \%$ higher. $^{25}$ (see Table 1) This is a classic example of how local air pollution standards can have indirect and deleterious effects on national emissions. Operating costs for batch induction furnaces increase $1.7 \%$ relative to the cupola furnace. These findings reflect the coal-based electricity system in Wisconsin and could be quite different in locations with lower power sector emissions and/or other non-coal energy sources.

\section{Advanced Oxidation with Hydroacoustic- Cavitation}

A U.S. based company has devised an advanced oxidation system that applies ozone, hydrogen peroxide, and sonication in a water-slurry. This system reprocesses baghouse waste dust, via a slurry known as "black water." The baghouse dust slurry is treated with advanced oxidation; and replaces the conventional water source for the green sand molds. Previously published papers indicate that the process requires $27-60 \%$ less clay and coal and 20-37\% less silica sand and produces $19-70 \%$ lower VOC air pollution during pouring, cooling, and shakeout. ${ }^{1-6,8}$ Fifty iron casting production lines have installed the system.

An enhanced upgrade of this process also includes hydroacoustics, cavitation, recirculation, and virtual cyclone (AO-HAC). AO-HAC has been installed on 10 U.S. foundry lines. This process acoustically dislodges the hydrophobic carbonaceous coating that accumulates on sand and clay grains. ${ }^{9,10}$ The carbonaceous coating forms when volatiles are pyrolyzed from the coal and binders near the molten iron surface; then the VOCs migrate into the (cooler) green sand mold, where they recondense on the grains. These advanced oxidation processes dislodge the condensed volatiles from the clay and sand surfaces in a manner that restores the hydrophilic binding propensity of the clay and sloughs them off in a manner that precludes them from re-volatilizing as VOC air pollution in the green sand's subsequent cycle through molding, pouring, cooling and shakeout.
In pilot-scale production, ${ }^{12}$ Fox et al. processed green sand with the AO-HAC system. The reclaimed sand was clean enough to use as core sand. When used in a full-scale demonstration, the cores made with reclaimed sand yielded iron castings that were equal or better quality than when using pristine commercial sand. The AO-HAC system has now been installed full-scale at the foundry and can reclaim $85 \%$ of the sand from used green sand. Based on this performance data and the synergistic effects of AO-HAC relative to AO$\mathrm{BW}$, the Table 2 life cycle and cost comparison tabulates that when the AO-HAC system is used for baghouse dust only, it can achieve the following reductions; $38 \%$ for clay and coal, $20 \%$ for new sand, $8.6 \%$ for home iron scrap, $41 \%$ for VOCs, (with a payback period of 0.4 years). When the AO-HAC system is used for both green sand and baghouse dust, the reductions can be $85 \%$ for new sand and $50 \%$ for clay and coal with a 0.3 year payback period. The rate of adoption of this process is accelerating.

\section{Collagen-Alkali Silicate Based Binders}

Conventional foundries commonly employ a cold box coremaking process using a phenolic urethane binder, cured with a strong-smelling amine gas, such as triethylamine (TEA) or dimethylethylamine (DMEA) that, when purged from the core, create air pollution. Moreover, when the cores are subjected to molten metal in the mold, these core binders pyrolyze and release VOCs and HAPs. These conventional core binders represent the predominant source of VOC and

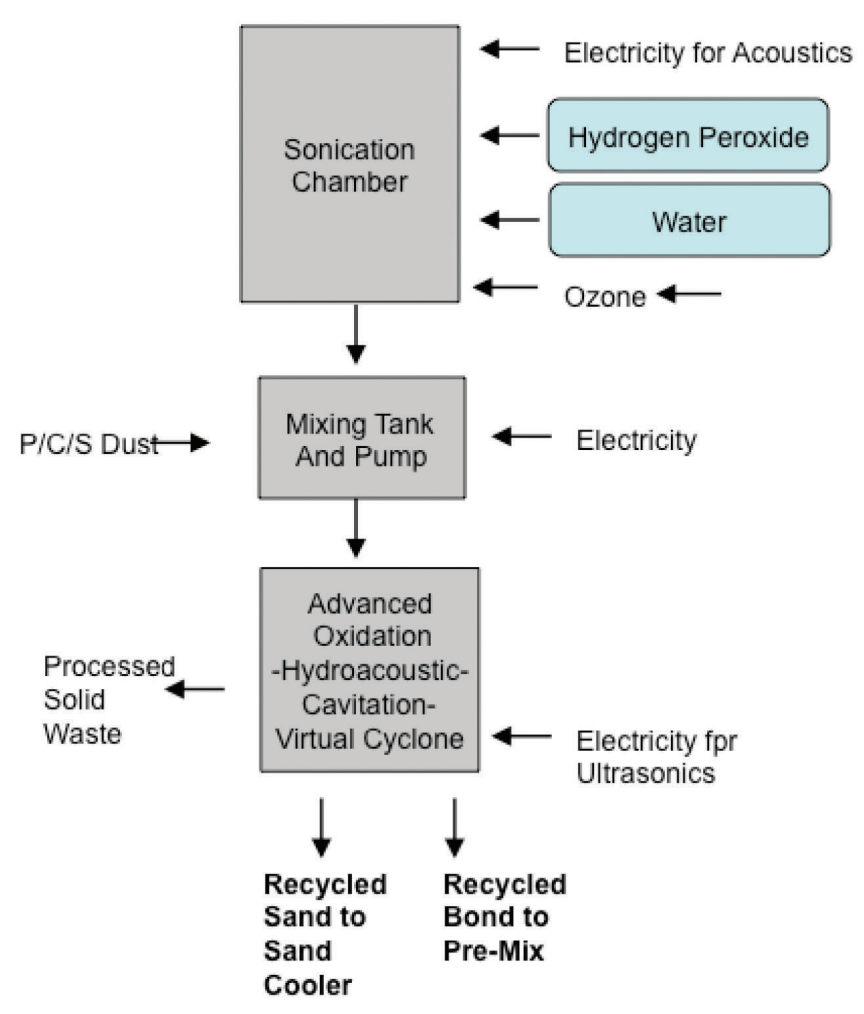

Figure 2. Advanced oxidation - Hydroacoustic-cavitation for reclaiming green sand and baghouse dust. 
HAP air pollutants from foundries. ${ }^{3,4}$ The authors note other conventional means of processing cores, which are beyond the scope herein, are used.

Recent bench-scale and pilot-scale trials by Wang et al. ${ }^{11,}$ 19-21 have shown a hybrid of collagen plus alkali silicates will create a core binder that emits far less VOCs and HAPs than phenolic urethane binders, while retaining the comparable strength and thermal resistance of conventional phenolic urethane. ${ }^{15}$ During the curing of the collagen-silicate hybrid, a proprietary system for heat-curing blown sand-binder systems warms the core box by heating it with air, moisture, or carbon dioxide under vacuum. The system requires investment in a modified core machine and special proprietary instrumentation but it does not require an amine scrubber and it does not produce scrubber brine that must be recovered. The only emission from the core shop is water. Based on limited partner foundry experience, this optimized coremaking process will be more efficient, with lower cycle time, less core box cleaning, and less core scrap than for conventional coremaking.

Recent studies report full-scale demonstrations of the low-emission hybrid core binder have been conducted, as described below. These studies are awaiting publication so this data is offered only as potential improvement. The anticipated favorable impacts that can be achieved with collagen-alkali silicate-based binders for green sand molds are presented in Table 3. This process reduces total operating costs by $1.3 \%$ and emissions of VOCs by $35 \%$ from the baseline plant. Some foundries are facing stringent limits on their allowable emissions of volatile organic compounds. Once they reach these limits, the foundry may need to operate at a lower production rate and/or resort to outsourcing from other domestic or foreign producers. The significant benefits of avoiding outsourcing by preventing rival producers from capturing market share are not incorporated in Table 3 .

\section{Coke and Seacoal Replacement Technologies}

To produce foundry coke, bituminous coal must be heated to $900-1000^{\circ} \mathrm{C}\left(1652-1832^{\circ} \mathrm{F}\right)$ for $28-30$ hours, consuming $15-20 \%$ of the raw coal's energy and releasing an equivalent amount of its carbon as greenhouse gases and VOCs. ${ }^{17}$ Two innovative technologies are available that avoid these emissions by either partially or completely replacing coke in iron foundry production. Yet a third proposed technology capitalizes on the exhausted heat from a cupola to yield a lignite-based activated carbon in-situ. This activated lignite then can adsorb VOC emissions and the loaded lignite then can be used in green sand molds in lieu of some bituminous seacoal and as feedstock for a brick formed coke replacement.
The first of these options is to use brick formed anthracite fines as a coke replacement. Huang et al. ${ }^{16,17}$ and Lumadue et al. ${ }^{18}$ used waste anthracite fines formed into bricks to partially replace coke and ferrosilicon (see Figure 3). These bricks have used binder materials made from collagen, silicon/silicate, and other biomaterials to match the strength and

Table 2. Advanced Oxidation-Hydroacoustic Cavitation-Virtual Cyclone: Impacts in Percentage Changes from Conventional Baseline, When Applied to Just Baghouse Dust, or When Applied to Both Baghouse Dust Plus Spent Green Sand

Total System Including Foundry plus Upstream (+ increase, - reduction)

\begin{tabular}{|c|c|c|}
\hline & $\begin{array}{c}\text { Baghouse } \\
\text { Dust }\end{array}$ & $\begin{array}{l}\text { Baghouse } \\
\text { plus green } \\
\text { sand }\end{array}$ \\
\hline \multicolumn{3}{|l|}{ Energy } \\
\hline Fossil & -0.6 & -0.6 \\
\hline Non-fossil & -0.6 & -0.6 \\
\hline \multicolumn{3}{|l|}{ Emissions } \\
\hline Greenhouse gas & -1.2 & -1.7 \\
\hline Criteria pollutants & -0.6 & -0.6 \\
\hline Particulates & -12.4 & -50.6 \\
\hline VOC & -24.1 & -24.1 \\
\hline \multicolumn{3}{|c|}{ Foundry Facility } \\
\hline \multicolumn{3}{|l|}{ Materials } \\
\hline New sand & -4.4 & -85 \\
\hline Phenolic resin & -0.7 & -0.7 \\
\hline Clay & -38 & -50 \\
\hline Seacoal & -38 & -50 \\
\hline Cereal & -38 & -50 \\
\hline Soda Ash & -38 & -50 \\
\hline Coke, pig iron, scrap, other & -0.7 & -0.7 \\
\hline Home scrap & -8.6 & -8.6 \\
\hline VOC - pouring, cooling, shakeout & -41.4 & -41.4 \\
\hline \multicolumn{3}{|l|}{ Costs } \\
\hline Energy & -0.6 & -0.6 \\
\hline Labor & -0.7 & -0.7 \\
\hline Materials & -2.9 & -6.9 \\
\hline Other Cost & -1.1 & -1.3 \\
\hline Total & -1.5 & -3 \\
\hline Payback in years & 0.4 & 0.3 \\
\hline
\end{tabular}

Table 3. Collagen-Alkali Silicate Binders: Potential Impacts in Percentage Changes from Conventional Baseline

\begin{tabular}{lc}
\hline & $\begin{array}{c}\text { Foundry Facility } \\
\text { (+ increase, - reduction) }\end{array}$ \\
\hline VOC emissions & -35.0 \\
Costs & \\
$\quad$ Labor & -7.6 \\
Materials & 5.8 \\
Other Cost & -3.6 \\
Total & -1.3 \\
Payback in years & 0.4 \\
\hline Bench tests and full-scale trials have been conducted. \\
\hline
\end{tabular}


energy value of coke. The anthracite fines and biomaterials used in these bricks otherwise have limited value as a lowgrade fuel or are otherwise thrown away as waste. Also, the bricks include silicon, which is otherwise charged into the cupola to provide Si to the cast iron and control the cupola's redox level. These bricks include $85 \%$ anthracite fines, $10 \%$ biomaterials, and $5 \%$ silicon/silicate. The binders become thermally conditioned in-situ within the cupola to provide strength from ambient temperature up to iron melting temperature. Lumadue et al. ${ }^{18}$ found these bricks have $35-40 \%$ higher BTU content per volume than coke and they burn as fast as coke. The research and development team recently demonstrated these formed anthracite bricks in a full-scale cupola foundry in Pennsylvania. This trial employed 4 tons of bricks formed with biomaterials, with $25 \%$ substitution of the bricks for coke during a half-day duration. The bricks remained intact during the rough handling when charged into the cupola and they were observed still intact as they descended to the tuyere windows, where temperatures reached $1550^{\circ} \mathrm{C}\left(3000^{\circ} \mathrm{F}\right)$. At the tuyere level, the bricks rapidly burned (but not before). During this brick substitution, the total carbon charged into the furnace (i.e. carbon in the coke plus bricks) was decreased by $6 \%$, while maintaining a constant melt temperature achieving a more favorable $\mathrm{CO} /$ $\mathrm{CO}_{2}$ ratio than with mere coke, and maintaining a favorable olive-green slag color that indicated suitably reduced conditions for metallic iron formation. The carbon content of the iron product remained constant, while the iron also maintained acceptable levels of $\mathrm{Si}, \mathrm{S}$, and other trace metals. The demonstration(s) at this foundry have shown the iron product quality is also maintained.

The more effective energy release could diminish natural gas requirements in foundries that also inject supplemental natural gas into the cupola. The life cycle analysis herein assumes waste anthracite fines will be manufactured into bricks at an eastern Pennsylvania coal mine and the other ingredients will be transported a day's drive to this site. These will include, the collagen, which is a byproduct of meat processing. The anthracite bricks must be dried at $120^{\circ} \mathrm{C}$ $\left(248^{\circ} \mathrm{F}\right)$, which involves minor energy use-considerably less than for coking coke at $900-1000^{\circ} \mathrm{C}\left(1652-1832^{\circ} \mathrm{F}\right)$ for 26-30 hours.

This life cycle and cost study estimates the impacts of two variations of this coke replacement strategy: 20\% and 50\% replacement of coke with anthracite bricks held together with biomaterial. In light of the energy consumed when making coke, the coal-related life cycle energy potentially diminishes $0.6 \%$ when using $20 \%$ coke substitution, or $1.5 \%$ when using $50 \%$ brick substitution (see Table 4 ). The net life cycle energy related to transportation will be unchanged by this substitution. The anthracite bricks will travel from the eastern Pennsylvania anthracite mines to the Wisconsin foundry. In comparison, the bituminous coal would be shipped from West Virginia or southwestern Pennsylvania to the coking plants in Erie, Pennsylvania, or Niagara, New York; the cok- ing process would decrease the coal's weight by 15-20\%; and then the coke product would be shipped to Wisconsin. The net transportation for these two scenarios is roughly equal, when also considering the bricks contain 10-15\% other components that would be transported a day's drive to a brick-making site in eastern Pennsylvania. Emissions of criteria air emissions fall from $3 \%$ to almost $7.5 \%$ below baseline levels as the rate of coke replacement varies from 20 to $50 \%$. There are also potentially significant reductions in emissions of greenhouse gases and volatile organic compounds (see Table 4).

Another innovation is to use the waste heat from the cupola to pyrolyze lignite coal in-situ. This will produce activated carbon fines that can be blown into the exhaust ducts from pouring/cooling/shakeout, to adsorb VOCs both in the ducts and in the baghouse dust. ${ }^{23,24}$ The pyrolyzed lignite then can be recirculated with the baghouse dust back into the green sand system. There, the carbon from the lignite and the scavenged VOCs can displace some of the seacoal. The operating costs for this process are mostly electricity for material handling equipment. Notably, the energy required for pyrolyzing the lignite originates from cupola waste heat, and the associated emissions can be injected back into the cupola.

The emissions reductions occur because the activated lignite will adsorb VOCs that would otherwise be exhausted as air pollution. Full-scale trials at Neenah foundry appraised the cooling and shakeout emissions reductions that could potentially be achieved by this innovation. ${ }^{24}$ These trials employed a commercial lignite activated carbon as a surrogate for in-situ activated lignite. This was dosed at $3.0 \mathrm{mg} / \mathrm{scf}$ (standard cubic

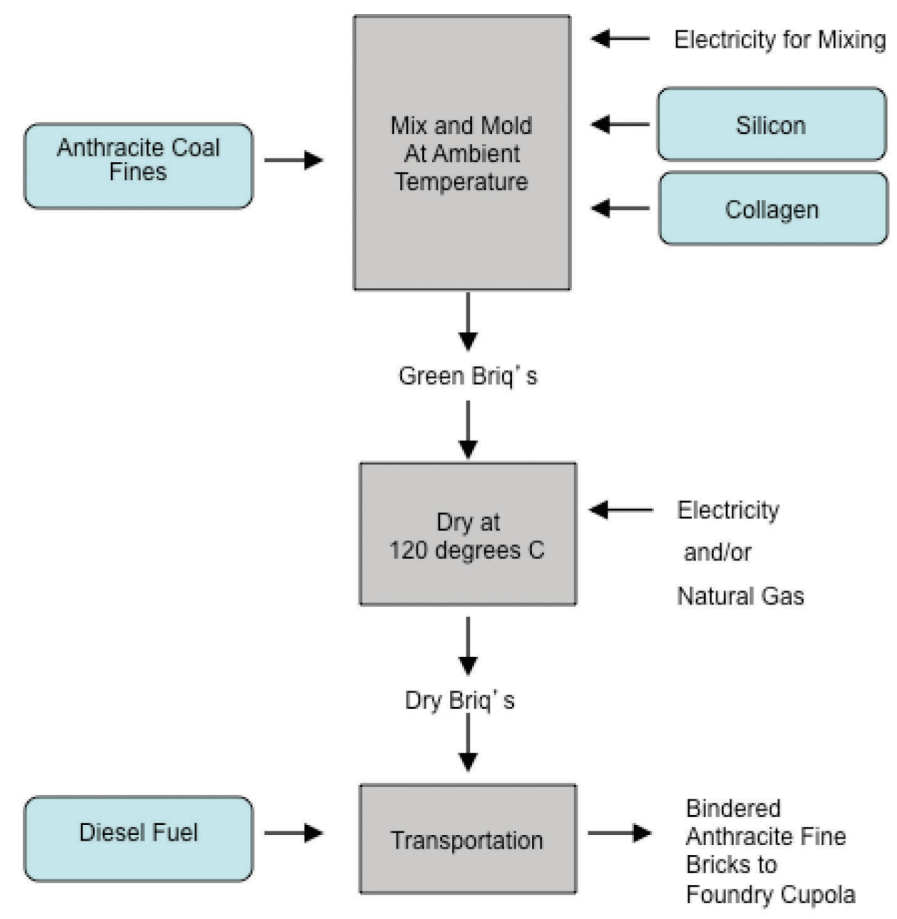

Figure 3. Coke replacement with anthracite fines. 
feet) into the stack gas duct. The contact time was $0.56 \mathrm{sec}-$ onds ahead of the baghouses and 0.32 seconds within the baghouse fabric's accumulated solids. While this lignite activated carbon was used, the baghouse exhaust released 0.26-0.34 lbs. VOCs/ton Fe (average 0.3), whereas without the activated carbon, the exhaust averaged $0.46 \mathrm{lbs}$. VOCs/ton Fe. Thus, such in-situ-generated activated carbons could likewise offer a roughly $23 \%$ decrease in total VOCs (Table 4 ).

Another potential coke replacement technology is to use waste heat from the cupola to start pyrolysis of granular bituminous coal that can be made into briquettes using the same binder materials mentioned above. The by-products of this process could be sold and/or used as fuel. Direct and indirect labor is needed for this process as it takes place within the foundry. Emission reductions are based on the reduced energy required to complete this process. Volatile organic compounds are condensed as a byproduct or burned directly in the cupola. This process has been successfully demonstrated in a full-scale foundry trial and also can produce material suitable to replace metallurgical coke.

This process generates potential energy savings of $3 \%$ (see Table 4), which does not include the energy available in the sold byproducts. Greenhouse gases are reduced by $2.8 \%$.

Table 4. Coke and Seacoal Replacement: Potential Impacts in Percentage Changes from Conventional Baseline

\begin{tabular}{|c|c|c|c|c|}
\hline & \multicolumn{2}{|c|}{$\begin{array}{c}\text { Anthracite } \\
\text { Fines for } \\
\text { Brick for Coke }\end{array}$} & \multirow[t]{2}{*}{$\begin{array}{l}\text { In-situ } \\
\text { Activated } \\
\text { Lignite for } \\
\text { Seacoal }^{3}\end{array}$} & \multirow[t]{2}{*}{$\begin{array}{c}\text { In-Situ } \\
\text { Pyrolyzed } \\
\text { Bituminous } \\
\text { Coal Bricks }\end{array}$} \\
\hline & $20 \%^{1}$ & $50 \%{ }^{2}$ & & \\
\hline \multicolumn{5}{|c|}{ Total System Including Upstream (+ increase, - reduction) } \\
\hline \multicolumn{5}{|l|}{ Energy } \\
\hline Fossil & -0.6 & -1.5 & -0.6 & -3.0 \\
\hline Non-Fossil & -0.6 & -1.5 & -0.6 & -3.0 \\
\hline \multicolumn{5}{|l|}{ Emissions } \\
\hline Greenhouse Gas & -0.4 & -0.6 & -0.4 & -2.8 \\
\hline Criteria Pollutants & -3.0 & -7.5 & -2.9 & -14.9 \\
\hline Particulates & -3.3 & -8.3 & -3.3 & -3.3 \\
\hline VOC & -0.3 & -0.7 & -23 & -1.3 \\
\hline \multicolumn{5}{|c|}{ Foundry Facility (+ increase, - reduction) } \\
\hline \multicolumn{5}{|l|}{ Materials } \\
\hline Seacoal & & & -100 & \\
\hline Coke (as alloy) & & & & -100 \\
\hline Ferro-Alloys & -5.8 & -11.5 & & \\
\hline \multicolumn{5}{|l|}{ Costs } \\
\hline Energy & -5.6 & -14.0 & -7.6 & -19.6 \\
\hline Labor & & & & 3.8 \\
\hline Materials & -0.5 & -1.3 & 0.1 & -9.5 \\
\hline Other Cost & & & -16.8 & -157.1 \\
\hline Total & -0.9 & -2.2 & -2.7 & -20.6 \\
\hline Payback in years & 0 & 0 & 4.2 & 2.0 \\
\hline
\end{tabular}

The criteria pollutant and VOC emissions improve dramatically due to the closed nature of the process (see Table 4). Overall costs are reduced $20.6 \%$, with some negative impact on labor costs offset by reduced material and energy costs. Income from the sale of byproduct materials is substantial with impact shown in "other costs," making the net payback approximately two years.

\section{Foundry of the Future: Combined Innovative Technologies}

The most significant cost, energy, and material savings would occur when foundries adopt a combination of these innovative technologies. One such strategy combines:

- $50 \%$ coke replacement with anthracite fine bricks held together with biomaterial;

- Advanced oxidation-hydroacoustic cavitation for reclaiming green sand and baghouse dust; and

- Collagen-alkali silicate binder with previously described core machine technology.

Some of these options are symbiotic. For example, when a water-based low-emission collagen-alkali silicate binder is used rather than phenolic urethane binder, the VOC and HAP pollution will be diminished not only during the binder's first exposure to molten iron, but also during subsequent passes as the advanced oxidation process cleans the sand and clay grains. Additionally, the water-based advanced oxidation system will potentially clean the water-based binder residuals off core sand better than it will clean the residual phenolic urethane binders off core sand that enters the green sand system at shakeout.

Table 5 presents the life cycle and cost analysis for synergistically combining these three innovative technologies. This "foundry of the future" could offer a $15 \%$ decrease in life cycle energy costs, $85 \%$ decrease in new sand, $50 \%$ decrease in clay, coal, and coke, $57 \%$ decrease in VOCs, and $9 \%$ decrease in home iron scrap. Overall, this could translate to a $6.6 \%$ decrease in total costs. Clearly, this example illustrates that by employing these innovative processing technologies, a foundry can achieve substantial reductions in emissions, energy, and cost.

\section{Conclusions and Policy Implications}

This article tracks material and energy flows and costs in ductile iron castings production using conventional and advanced production techniques. Advanced oxidation systems that recycle baghouse dust and sand offer clear cost savings and environmental benefits. For this reason and others, they have been adopted by at least 60 foundry lines in the U.S. 
This study also estimates the impacts of replacing phenolic urethane binders with hydrolyzed collagen-alkali silicate binders and replacing metallurgical coke with an anthracite fines brick held together with biomaterial. These technologies represent an evolution of synergistic strategies for reclaiming otherwise wasted materials, such as baghouse dust and spent green sand, by employing advanced oxidation processes. The operating costs savings from adopting these sustainable technologies are significant relative to the investment requirements, and they yield fast payback periods of 0.2-1.4 year's payback for the process specific equipment plus installation expenses depending on system size. Given dwindling supplies and higher prices for high-grade metallurgical grade coal for coke making, coke replacement could provide significant cost-savings. This study demonstrates that re-using and substituting waste materials can meet more stringent environmental standards. If the coke replacement technologies considered here were also adopted in the steel industry, the ramifications would be profound. This could significantly reduce emissions and cut reliance upon dwindling world supplies of metallurgical grade coal.

Table 5. Foundry of the Future with Combined Three Innovations: Potential Impacts in Percentage Changes from Conventional Baseline

\begin{tabular}{lc}
\hline \multicolumn{2}{c}{ Total System Including Upstream (+ increase, - reduction) } \\
\hline Energy & -2.0 \\
Fossil & -2.1 \\
Non-fossil & \\
Emissions & -7.5 \\
Greenhouse Gas & -8.0 \\
Criteria Pollutants & -58.8 \\
Particulates & -60 \\
VOC $\quad$ Foundry Facility (+ increase, - reduction) & \\
& \\
Materials & -85 \\
New Sand & 17.2 \\
Collagen & -50 \\
Clay, seacoal, cereal, soda ash & -50 \\
Coke & -0.7 \\
Coke, iron, \& scrap & -8.6 \\
Home Scrap & -10.3 \\
Ferro-Alloys & -0.7 \\
Other Materials \& gases & \\
Costs & -14.7 \\
Energy & -8.3 \\
Labor & -2.3 \\
Materials & -4.9 \\
Other Cost & -6.6 \\
Total & 0.2 \\
Payback in years & \\
\hline Note: Future foundry includes (a) 50\% coke replacement with anthracite fine brick \\
held together with biomaterial, (b) advanced oxidation-hydroacoustic cavitation-virtual \\
cyclone for reclaiming both green sand and baghouse dust; and (c) collagen-alkali \\
silicate binder with proprietary system for heat-curing blown sand-binder system, to \\
replace phenolic urethane core binders. \\
\hline
\end{tabular}

\section{Acknowledgements}

The research and development regarding these innovative technologies that is chronicled herein has been funded through numerous grants from the National Science Foundation (NSF), U.S. Department of Agriculture (AFRI 201167009-20049), Department of Energy (Consortium for Premium Carbon Products from Coal), the Environmental Protection Agency, the Ben Franklin Technology Partners of Pennsylvania, and numerous industrial sources. The NSF grants include: 9816232, 0070183, 0524940, 0700759, 0824406, 0927967, 0906271, 1127817.

The authors of this paper recognize the important and extensive contributions of numerous people who have collaborated in this 15-20 year adventure toward sustainable manufacturing, including the following. The Pennsylvania State University: Sridhar Komarneni, Frank A. Clemente, Nicole R. Brown, Dave A. Neill, Joshua P. Land, Kimberly (Hoffman) Crawford, Nohami Milan Segovia, Matthew R. Lumadue, Yujue Wang, Joel E. Firebaugh, Jason K. Clobes, Magda Salama, Allura M. Jiles, Cesar Nieto Delgado, Joshua F. Allen, Zilong Zhao, Curtis W. Frantz, Paul J. Munson, Mike D. Morgan, Brian Widener, Mike J. Greenwald, M. Isabel Montante Zermano; Furness-Newburge: P. David Paulsen, Lynn Furness, Adam Brentzel; Harrison Machine Company: Patrick Farver, David Kidder; J.B. DeVenne Inc.: James A. DeVenne Jr.; Entelechy: Greg Sanders; Massachusetts Institute of Technology: Timothy G. Gutowski, Alissa J. Jones; Neenah Foundry (WI): Chuck M. Kurtti, Frank Headington, Steven E. Lewallen, Jon H. Andrews, Robert Karrels, Joe Giese, Matt Wosoba, Paul Smith, Dave Coan, Dave L. Sipple, H. Luebben, Mike Riabov; Wheland Foundry (TN) and Iron Casting Research Institute: Robert Bigge; Iron Casting Research Institute: Bruce T. Blatzer; Ward Foundry (PA): Kevin Barrron, William Walters, Jim Belawski, Paul Kurtz; HMAC Foundry (PA): James Lamonski, Anhua Yu, Robert Harter; International Truck and Engine Corp (WI): Matthew Redmann; Jeddo Coal: James R. Pagnotti; Ben Franklin Technology Partners: Larry A. Seibert.

\section{REFERENCES}

1. Andrews, J., Bigge, R., Cannon, F.S., Crandell, G.R., Furness, J.C., Redmann, M., Voigt, R.C., "Advanced Oxidants Offer Opportunities to Improve Mold Properties, Emissions," Modern Casting, pp. 40,43 (September, 2000).

2. Cannon, F.S., Goudzwaard, J.E., Peters, R.W., Furness, J.C., Voigt, R.C., Kurtti, C.M., Andrews, J.H., "Use of Advanced Oxidation Technology for Emissions \& Materials Reduction at Foundries," Chemical Process Pollution Prevention Towards Zero Discharge, ed. Das, T.K.; John Wiley (2004).

3. Glowacki, C.R., Crandell, G.R., Cannon, F.S., Clobes, J.K., Voigt, R.C., Furness, J.C., McComb, B.A., 
Knight, S.M., "Emissions Studies at a Test Foundry using an Advanced Oxidation-Clear Water System," AFS Transactions, vol. 111, pp. 579-598 (2003).

4. Goudzwaard, J.E., Kurtti, C.M., Andrews, J.H., Cannon, F.S., Voigt, R.C., Firebaugh, J.E., Furness, J.C., \& Sipple, D.L., "Foundry Emissions Effects with an Advanced Oxidation Blackwater System," AFS Transactions, vol. 111, pp. 1191-1211 (2003).

5. Land, J.D., Cannon, F S., Voigt, R.C., and Goudzwaard, J.E, "Perspectives on Foundry Air Emissions: A Statistical Analysis Approach," AFS Transactions, vol. 112, p. 1075 (2004).

6. Land, J.D., Voigt, R C., Cannon, F S., Furness, J C., Goudzwaard, J.E., Luebben, H., "Performance and Control of a Green Sand System During the Installation and Operation of an Advanced Oxidation System," AFS Transactions, vol. 110, pp. 705-713 (2002).

7. Milan-Segovia, N., Wang, Y.J., Cannon, F.S., Voigt, R.C., Furness, J.C., "Comparison of Hydroxyl Radical Generation for Various Advanced Oxidation Combinations as Applied to Foundries," Ozone Sci. \& Engr., vol. 29 (6), pp. 461 (2007).

8. Neill, D.A., Cannon, F.S., Voigt, R.C., Furness, J.C., Bigge, R.H., "Effects of Advanced Oxidants on Green Sand System Performance in a Black Water System," AFS Transactions, vol. 109, pp. 937-955 (2001).

9. Wang Y.J., Cannon, F.S., Komarneni, S., Voigt, R.C., Furness, J.C., "Mechanisms of Advanced Oxidation Processing on Bentonite Consumption Reduction in Foundry," Environ. Sci. Technol., vol. 39, pp. 77127718 (2005).

10. Wang, Y.J., Cannon, F.S., Neill, D.A., Crawford, K., Voigt, R.C., Furness, J.C., Glowacki, C.R., "Effects of Advanced Oxidation Treatment on Green Sand Properties and Emissions," AFS Transactions, vol. 112, pp. 635-648 (2004).

11. Wang, Y.J., Cannon, F.S., Li, X.G., “A Comparative Analysis of Hazardous Air Pollutant Emissions of Casting Materials Measured in Analytical Pyrolysis and Conventional Metal Pouring Emission Tests," Environ. Sci. Technol., vol. 45, no. 19, pp. 8529-8535 (2011).

12. Fox, J.T., Cannon, F.S., Voigt, R.C., Furness, J.C., Headington, F., Coan, D., Lewallen, S.E., "Waste Green Sand to Core Sand Reclamation, Demonstration via Casting Study with Simultaneous Clay Recovery via a Novel Ultrasonic-Cavitation System," AFS Transactions, vol. 116, pp. 523-538 (2008).

13. Fox, J.T., Cannon, F.S., Voigt, R.C., Furness, J.C., Goudzwaard, J.E., Wosoba, M., Smith, P.B., "Decreased Bond Consumption by Processing Baghouse Dust through Ultrasonic-Cavitation-Settling Coupled to Advanced Oxidation," AFS Transactions, vol. 116, pp. 539-546 (2008).

14. Fox, J.T., Cannon, F.S., Voigt, R.C., Furness, J.C., Smith, P.B., Lewallen, S.E., Goudzwaard, J.E., "Simultaneous Sand, Clay and Coal Reclamation
Using Induced Particle Collision, Discretionary Settling and Advanced Oxidation," AFS Transactions, vol. 115, pp. 367-382 (2007).

15. Fox, J.T., Cannon, F.S., Brown, N.R., Huang, H., Furness, J.C., "Comparison of a New, Green Foundry Binder with Conventional Foundry Binders," Int. J. Adhes. Adhes., vol. 34, pp. 38-45 (2012).

16. Huang, H., Fox, J.T., Cannon, F.S., Komarneni, S., "In Situ Growth of Silicon Carbide Nanowires from Anthracite Surfaces," Ceram. Int., vol. 37(3), pp. 10631072 (2011).

17. Huang H., Fox, J.T., Cannon, F.S., Komarneni, S., Kulik, J., Furness, J.C. "Binding Waste Anthracite Fines with Si-Containing Materials as an Alternative Fuel for Foundry Cupola Furnaces," Environ. Sci. Technol.," vol. 45 (7), pp. 3062-3068 (2011a).

18. Lumadue, M.R., Cannon, F.S., Brown, N.R., "Lignin as Both Fuel and Fusing Binder in Briquetted Anthracite Fines for Foundry Coke Substitute," Fuel, vol. 97, pp. 869-875 (2012).

19. Wang, Y.J., Cannon, F.S., Salama, M., Fonseca, D. A., Giese, S., "Characterization of Pyrolysis Products from a Biodiesel Phenolic Urethane Binder," Environ. Sci. Technol., vol. 43(5), pp. 1559-1564 (2009).

20. Wang, Y.J., Huang, H., Cannon, F.S., Voigt, R.C., Komarneni, S., Furness, J.C., "Evaluation of Volatile Hydrocarbon Emission Characteristics of Carbonaceous Additives in Green Sand Foundries," Environ. Sci. Technol., vol. 41(8), pp. 2957-2963 (2007).

21. Wang, Y.J., Cannon, F.S., Salama, M., Goudzwaard, J., and Furness, J.C., "Characterization of Hydrocarbon Emissions from Green Sand Foundry Core Binders by Analytical Pyrolysis," Environ. Sci. Technol., vol. 41(22), pp. $7922-7927$ (2007).

22. Wang, Y.J., Cannon, F.S., Voigt, R.C., Komarneni, S., Furness, J.C. "Effects of Advanced Oxidation on Green Sand Properties via Iron Casting in Greensand Molds," Environ. Sci. Technol., vol. 40(9), pp. 30953101 (2006).

23. Huang, H., Wang, Y.J., and Cannon, F.S., "Pore Structure Development of In-Situ Pyrolyzed Coals for Pollution Prevention in Iron Foundries," Fuel Processing Technology, vol. 90(9), pp. 1183 (2009).

24. Cannon, F.S., Huang, H., Wang, Y.J., Voigt, R.C., Clobes, J., Goudzwaard, J.E., “Adapting Anthracite Coal and Stockpiled Anthracite Fines to Green Sand Iron Foundries," DOE Consortium for Premium Carbon Products from Coal Final Report (April, 2006).

25. Jones, A.J., "The Industrial Ecology of the Iron Casting Industry," Masters Thesis, Massachusetts Institute of Technology, Mechanical Engineering (2007).

26. Considine, T.J., Jablonowski, C.J., Considine, D.M. "The Environment and New Technology Adoption in the U.S. Steel Industry," The Pennsylvania State University (2001). 
27. Alsema, E.A., Phylipsen, G.J.M., "Environmental Life Cycle Assessment of Multicrystalline Silicon Solar Cell Modules," Utrecht: Department of Science, Technology and Society, Utrecht University (1995).

28. Baumel, C.P., Hurburgh, C.R., Lee, T., and Iowa Agriculture and Home Economics Experiment Station, "Estimates of Total Fuel Consumption in Transporting Grain from Iowa to Major Grain-Importing Countries by Alternative Modes and Routes," Ames, Iowa, Agriculture and Home Economics Experiment Station, Iowa State University of Science and Technology (1985).

29. Davis, S.C., Diegel, S.W., Boundy, R.G., “Transportation Energy Data Book: Edition 28," U.S. Department of Energy, pp. Table 2.12. ORNL-6984 (Edition 28 of ORNL-5198) (2009).

30. Facanha, C., Horvath, A., "Environmental Assessment of Freight Transportation in the U.S.," Int. J. of Life Cycle Assess., vol. 11(4), pp. 229-239 (2006).

31. Rodrigue, J.P., Comtois, C., Slack, B., "Chapter 7 - Transportation and the Economy," from The Geography of Transport Systems, New York, NY: Routledge, http://people.hofstra.edu/geotrans/eng/ ch7en/ch7menu.html. (2009).

32. U.S. Energy Information Administration, "Voluntary Reporting of Greenhouse Gases Program," http://www.eia.gov/oiaf/1605/emission factors. html\#emission. As downloaded on July 26, 2010a.
33. U.S. Energy Information Administration, "Coal Transportation: Rates and Trends," http://www.eia.gov/coal/transportationrates/trend-coal. cfm. As downloaded on August 26, 2010b.

34. U.S. Energy Information Administration, "State Energy Profiles: Wisconsin," http://tonto.eia.doe.gov/state/state energy profiles. cfm?sid=WI . As downloaded on July 13, 2010c.

35. U.S. Energy Information Administration, "Gasoline and Diesel Fuel Update," http://www.eia.gov/ petroleum/gasdiesel/ As downloaded on August 26, $2010 d$.

36. U.S. Environmental Protection Agency, "Greenhouse Gas Inventory Report," http://www.epa.gov/climatechange/emissions/ usinventoryreport.html. As downloaded on July 8, 2010a.

37. U.S. Environmental Protection Agency, "AP-42 Compilation of Air Pollutant Emission Factors: Stationary Point and Area Sources," http://www.epa. gov/ttnchie1/ap42/. As downloaded on August 27, $2010 b$. 